\title{
The Role of Culture in Teaching English for Business Purposes
} GUELLIL Assia

Assistant professor of English, Ammar Theledji University, Laghouat, Algeria

\begin{abstract}
As English is becoming more and more the language of the global market, the teaching/ learning of English for business purposes is at risk of separating the language from its culture. However, cultural sensitivity is an integral part of the interaction between languages and thoughts in the business domain, especially in the field of international trade, which plays a vital role in the understanding of the way other people think, behave, act, and react accordingly. This paper aims at underscoring the essential role played by culture in both teaching and learning of English for commercial aims since the cultural context could not be divorced from its language. Hence, showing the extent to which language skills are tightly linked to the cultural paradigm is of paramount importance. Moreover, emphasizing the inseparability of language and culture would be demonstrated through the critical role played by culture in business and commerce classes, as well as how discarding culture could be an obstacle for the teaching and the learning of the language.
\end{abstract}

Keywords - Language and Culture; Teaching English for Business Purposes; Role of Culture.

In todays' world, English language is becoming the primary communication source of business globally, as well as many other social sectors. Subsequently, the main reason behind holding the title of the international language, is that English acquisition is a linguistic competence which would favour its learner over learning any other languages for the simple fact that he is going to communicate with different people worldwide not only English-speaking ones.Hence, the learning of English is a quite essential process in regards of the educational as well as the professional levels. Schools, universities, enterprises, companies, and many other international institutions opt for teaching and learning English, simply because it is the most commonly used foreign language.

In business, English is again the dominant language in the global market place. Thus, for work opportunities and more advantages for those who are interested in entering the work force whether be a student of business and commerce, a businessperson, or an entrepreneur, they all should apply for English courses. However, the teaching of English for business purposes in Algerian vocational, private schools, and even universities are predominantly preoccupied with providing the learners with well-condensed language courses that are purely linguistic and have nothing to do with teaching the language within its context.In other words, teaching English in in a contextualized situation and in relation to its culture is given less importance and attention.
This paper tackles the problem of teaching and learning English language out of its cultural context for business purposes in specific. Not with standing the challenges of teaching culture for business students who are ostensibly more concerned with the vocabulary used in business situations like negotiating, business meetings, telephoning, writing business letters. Therefore, this research tries to advance some strategies of using culture as a context for teaching Business English in order to make the learning of English both enjoyable and fruitful, besides rising the cultural awareness and openness of future business people to others' culture.

The demand over the teaching and learning of English for business purposes has been noticeably increasing over the last two decades. This remarkable need in acquiring English was due to the growing interest in the international business and commerce worldwide (Boyd, 1991).Yet, this newly initiated sub-discipline of English for specific purposes (ESP), or ESP-B, has recently started being widely recognized in the field of teaching English.

It is eminently important to know about the underscored goals of teaching English for Business purposes. In fact, the studying of English in Business classes, in general, is heavily based on the communicative skills more than any other skill. Therefore, the main target in language acquisition for different business settings is to work more on the communicative competence that includes language skills as discourse and sociolinguistic competence. However, these oral skills are needed not 
only for an effective performance in business, but also in academic settings as well (Boyd,1991).

Culture is a concept that has different definitions and covers various societal aspects. Culture extends participating in the construction of a given history, arts, and traditions of a given group within a given society, to being the core of a certain people's mind-set (Marer, n.d.). The latter, which is our main interest in the process of teaching, is based on the way problems are solved, people are acting and reacting, thoughts are perceived and interpreted, etc. In this respect, the Dutch scholar, Fons Trompenaars (1993), relates culture to "the way in which a group of people solves problems" (p. 07). Yet, other scholars ${ }^{1}$ perceive culture as a much broader concept, apart from being a mere problem-solving key. Ned Seelye (1978), for example, stresses on the fact that culture "emerges as a very broad concept embracing all aspects of human life" (p. 13).

The broadness of this concept is handicapping the pedagogical operation to choose adequately the optimal scopes under which the teaching and the learning processes would be useful, beneficial, and effective all at once. Furthermore, culture is so vast that teachers could not cover in their courses all aspects of a given culture with its limitless themes, nor could their lectures be fruitful to deal with some unimportant facets of particular cultural components. According to Robert C. Lafayette (1978:1), the depiction of appropriate elements of culture to be part of a curriculum is not an easy job. He states that,

Because culture can be defined so broadly, it is often difficult for teachers to select those aspects that should be included in the curriculum at various levels of instruction. The choice ranges from supplying students with clearly identifiable cognitive facts about a culture to bringing about very subtle affective changes in their desire or ability to value people who think, dress, or act differently from themselves.

Thevariety and richness that dwell any culture leave the teacher confused upon what cultural knowledge would fit into his class, and meet his students' needs. Not with standing, the selection of the cultural subjects should initially deal with the observable cultural phenomena that are visible and knowable; moving to the conception of understanding and respecting the cultural differences, or moving from the explicit culture to the implicit one as Paul Marer best describes it. According to him, the explicit culture stands for the seen and observed cultural facts as certain peoples' rituals, behaviours, common habits, and etiquettes that we should know about. The implicit culture, however, is the hidden part that we should investigate for ensuring mutual respect and shared understanding. It contains the beliefs and values of cross-cultural matters in general. Hence, introducing cultural matters in any pedagogical setting requires a deep thinking of what would be suitable for the aim set by the teacher.

Accordingly, the key point in understanding, learning, and teaching any culture in a very effective way, is to get into its different layers, and get closer to its various levels. In his book Riding the Waves of Culture, Fons Tropenaars(1993) pinpoints different layers of culture in a very elucidative manner. He contends, "Culture comes in layers, like an onion, to understand it you have to unpeel it layer by layer" (p. 06). As explained by Tropenaars, the first layer or outer layer represents the explicit or the seen particulars of a given culture. This includes language, architect, art, music, traditions. Middle layer, however, is mainly concerned with the norms found in any society, as what is accepted and refused, what is right and wrong, what is good and bad, etc. The third layer that is referred to as the core of a culture deals merely with the being and existence.

The levels of culture, however, has another categorization. Again, Tropenaars(1993) states that there are three levels in every culture: the national, corporate (or organisational) and professional level. Furthermore, those levels are predominantly needed and found in business and work place, as they focus on nation states, organizations, and corporations. The cultural factsat the professional level, for example, differ from one nation to another. This is to say that every country has its own national identity that was shaped due to a set of conventions. As it is well illustrated by Maurer in his description of the Japanese and Americans' cultural differences in business affairs. Americans are more individualistic compared to the Japanese who tend to be more collectivistic. Accordingly, Americans always aim at being universalist, that is to say that, in business situations, laws, rules and the framework come before relationships. However, the Japanese are more particularistic, giving more importance to relationships than rules.

Culture and language are two faces of the same coin. They could never be separated. Indeed, the only way of articulating culture properly is through language that constitutes a great part of culture construction. In pedagogy, the inseparability of language from culture is highly recommended in ESL and EFL classes due to the fact that language, in essence, is a cultural phenomenon that cannot be taught or learnt apart from the cultural 
context that is considered as an integral part of language teaching and learning. Douglas Brown (1986) expresses the same viewpoint by stating, "Culture is really an integral part of the interaction between language and thought. Cultural patterns, customs, and ways of life are expressed in language; culture specific worldviews are reflected in language" (p. 145).

Implementing culture in English language courses would be a rewarding academic experience. Since the acquired language is the major medium used for demonstrating and expressing the cultural components. The students, consequently, would notice that language being learnt and its culture are blended and combined into an integrated whole. Correspondingly, students would become more aware of an existing other, owning a different mind-set, with different thoughts and beliefs. The recognition of an already existing other would lead to comprehending and respecting the other, who has not only a different language, but most importantly a different culture(Suleiman, 1993).

In the business, success depends heavily on the well understanding of the other's culture. Consequently, it is predominantly important to integrate the cultural ingredient into the language-teaching recipe.Today, the world is witnessing a rapid increase in commerce and business globalization, the matter that resulted in an increasing need for more corporations, organizations, as well as consumers to enter world trade and work force on an international scale. By doing so, business worldwide is going to have more opportunities and open up to different qualitative markets globally. Thus, the need to know about culture, especially the one that belongs to the most controlling business internationally, is undoubtedly very crucial.

However, Introducing culture in Business classes needs a careful examination over the chosen cultural topics, as well as a good selection of the strategies and techniques that the teacher should adopt to ensure a well understanding of culture specificities. In fact, there are some problems facing the teaching of a foreign language culture, especially in the way it should be taught, this includes the right way of transmitting the cultural knowledge. This is to say thatculture could be taught to different levels through different methods with the use of different techniques. Furthermore, the appropriate adoption of the useful techniques for teaching culture in a Business class primarily through the acquisition of the linguistic competence is one of the most essential aspects of culture teaching and learning.

In this respect, a well-rounded language for business course should include cultural competence, which is defined as the ability to use the communicative aspect of a language, the understanding of culture knowledge, and the empathy towards the target culture (Saint Paul, 2010).According to the American Association of Teachers of French Commission ${ }^{2}$, cultural competence is a set of abilities that must be developed. Moreover, this vital competence in language learning and teaching includes cognitive abilities, behavioural skills and affective potentials. Similarly, the American Council on the Teaching of Foreign Languages (ACTFL) created the model of the Proficiency Guidelines that demonstrates different stages in the learning of cultural competence that is tightly linked to the different levels of language acquisition $^{3}$. These stages that are considered as the most visible levels for cultural proficiency ${ }^{4}$ are defined and performed in a form of testable cultural tasks that the learner must carry out and accomplish.

In order to engage the students in the business field actively in the process of acquiring English language and its culture, it is eminently important for teachers to recognize the need of integrating more cultural activities. This effective pedagogical practice would lead to a good understanding of cultural and intercultural issues, which would "help combat the ethnocentrism that often dominates the thinking of our young people" (National Standards in Foreign Language Education Project). Besides this, business students would improve the chances to succeed in the future business world. According to numerous researches 5 , a language class that does not favour contextualized and real life matters would not help the students to use the language appropriately. This is to say that the second language teaching and learning has remarkably changed over the last decades from being a mere grammar and vocabulary teaching class to a more inviting participatory class where the student moved from being a passive receptor of how to say things to an active producer of how to perceive and interpret things (Dema, 2012).Claire Kramsch(1991: 221) comments on the swift move from the traditional to the new way in teaching by stating, "Culture is commonly seen as making the study of a foreign language more attractive and as providing a welcome relief from grammar and vocabulary exercises.

\footnotetext{
2- The American Association of Teachers of French Commission developed a well-structured program for teaching the cultural skills. In order to demonstrate and proof the utility of this created program, the association conducted a research as part of summer program in France for a group of MBA business students.

44- Cultural Proficiency in education is the ability to go through different levels of knowledge-based skills that are required to successfully teach and interact with students.
} 
Learning about a foreign culture is not expected to require any intellectual effort since it is generally conceived only as the tourist's view of the foreign ways of life".

In order to promote the development of crosscultural competence, a variety of activities to teach culture could be included in EFL and ESL classrooms as an effective way for enhancing authentic communication, as well as rising cultural awareness among the learners, as the primary goal of culture teaching to business students is to make them aware of differences. In addition,the learners should be aware that their culture and the way they think is notthe only way. Subsequently, some exercises that focus on the linguistics skills within a specific cultural content, in order to deal with a certain professional or business framework are really needed for business students in a general sense, as well as learners who would be engaged in global competitive activities.

One of the most common business required tasks is letter writing. In fact, writing a business letterhas a simple and easy to learn format, yet it has definite cultural conventions that should be followed. For Susan Jenkins and John Hinds (1987), letter writing is a needed piece of writing in managerial work that requires some cultural knowledge, whether being the reader or the writer of this kind of letters. Again, Jenkins and Hinds found that ritualized discourse that is embedded in the business letter of request in any language unfolds crucial cultural attitudes and meanings.

Developing small talks could be another useful way for increasing the learners' knowledge about the targeted culture of the language being addressed. In this case, business students could deal with various topics that highlight cultural diversity conception for needed business situations that the students may encounter in their future professions. Introducing such cultural ideas as a way to know and understand the other and practicing speaking English simultaneously could be of a great help for the learners who are expected to be entrepreneur, businesspersons, executives, negotiators, etc. In a roleplay, for instance, the teacher could set the pace for the students in order to initiate a cultural notion that is different from theirs. Then, the students would be asked to practice making arrangements by using functional language that they have already acquired. After three to four times of small talk, the students are supposed to be engaged in a longer and more advanced talk level, in which they should be exposed to a class debate. The latter however, requires more structured and well-thought of subjects that should be recent, useful, and relevant to business settings at the same time.
In the present paper, I have tried to accentuate the importance of culture in English teaching in general, and the eminent role that cultural competence plays in empowering the communicative skills in business settings in specific. Special emphasis has been laid upon how culture could be part of the language acquisition in a professional context. In order to meet that underscored goal, a set of suggested tasks have been introduced in order to engage learners actively in the acquisition of language and culture and promote authentic genuine communication as well. By doing so, the teaching of the targeted language with reference to its culture would make a remarkable progress in the academia.Subsequently, in a global commercial and business world, it is crucial to bridge the gap between language and culture. In this respect, cross-cultural competence and cultural proficiency are really needed in English business classes. In such classes, the students are to be made aware of their own cultural knowledge and understanding of the culture of another language, besides the linguistic and communicative competence of the international language, English. It is worth noticing that introducing culture and cultural differences in business English courses is not a mere necessity, but it is a good way for enliven the teaching and learning processes.

Notes

1- In this respect, two American anthropologists, Kroeber \&Kluckhon, have identified 164 different definitions of the term culture (Özkalp, 1989; Sabuncu\&Emre, 1995; Gao, 2006).

2- The American Association of Teachers of French Commission developed a well-structured program for teaching the cultural skills. In order to demonstrate and proof the utility of this created program, the association conducted a research as part of summer program in France for a group of MBA business students.

3 - The stages are basically categorized under five essential elements that contribute to the ability to become culturally proficient which include:

1. Valuing diversity.

2. Having the capacity for cultural selfassessment.

3. Managing the dynamics of difference

4. Having institutionalized cultural knowledge.

5. Having developed adaptations to service/curriculum delivery reflecting an understanding of cultural diversity.

4 - Cultural Proficiency in education is the ability to go through different levels of knowledge-based skills that are required to successfully teach and interact with students. 
5- All of Firth \& Wagner, 1997; Hall, 1997; Stoller, 2006; and van Lier, 2000, count for the same idea.

\section{REFERENCES}

[1] Boyd, F. A. (1991). Business English and the Case Method: A Reassessment. TESOL Quarterly, 25, 729-734.

[2] Brown, Douglas H. (1986).Learning a Second Culture.Culture Bound: Bridging the cultural gap in language, edited by Joyce Merrill Valdes.

[3] Dema, Oxana and Moeller, Aleidine Kramer. (2012). Teaching culture in the 21st century language classroom.Faculty Publications: Department of Teaching, Learning and Teacher Education. Paper 181.

[4] Jenkins, S., \& Hinds, J. (1987). Business letter writing: English, French, and Japanese. TESOL Quarterly,21, (2), 327-349.

[5] Kramsche, C. (1991). Culture in Language learning: a view from the United States. de Bot, K., Ginsberg, R. B., Kramsch, C. (Eds.), foreign language Research in CrossCultural Perspective. 217-240.

[6] Lafayette, Robert C. 1978. Teaching Culture: Strategies and techniques. Arlington, Va.: Center for Applied Linguistics.

[7] Marer, Paul.N.d, Introducing Culture in Business Courses. $n, p$.

[8] Saint Paul,Thérèse. (2010). Developing Cultural Awareness with International Business Students: A Look at Empathy Breakdown.Global Business Languages, 5, Article 5.

[9] Seelye, H. Ned. (1978). Teaching Culture: Strategies for intercultural communication. Lincolnwood, I11. National Textbook Company.

[10] Suleiman, Yasir. (1993). TAFL and the Teaching/Learning of Culture: Theoretical Perspectives and an Experimental Module. Al-'Arabiyya, 26 (1993), 61-111.

[11] Trompenaars, F. (1993). Riding the Waves of Culture. Nicholas Brealey, London. 